\title{
Pengembangan Desain Batik Limbah Grajen di Bulakan Sukoharjo, Jawa Tengah
}

Fify Fitriani ${ }_{1}^{*}$, Setyawan2 1,2 Program Studi Kriya Tekstil, Fakultas Seni Rupa dan Desain, Universitas Sebelas Maret, Surakarta

\begin{abstract}
Grajen (sawdust) Batik is batik made using natural dye that comes from the waste of wood cutting that is in the form of timber powder (which is called Grajen in Javanese Language). Grajen Batik is developed in Bulakan Sukoharjo Java Tengah. Batik craftsmen in Bulakan region have dozens of years to pursue the process of batik and they have a specialization in the batik motif of parang, kawung, kopi pecah and tirtotejo. Batik motifs that evolve in Bulakan do not portray the typical characteristics of the Bulakan region, because batik craftsmen in Bulakan for tens of years have only been making the development of motifs. Therefore it is necessary to develop batik which has typical characteristics of the neighborhood where the craftsmen live in order to distinguish with batik existing in other regions.
\end{abstract}

This research used the method of qualitative research with approach to the design and ethnography, which aims for the design to be laid out as a product of culture in which the existence of batik does not appear on its own, but there is the context of socio-culture as well as underlying history.

Keywords: grajen batik, ethnography method, batik motifs, craft. Bulakan region

$\begin{array}{ll}\text { *Fify Fitriani } & \\ \text { Email } & \text { : fifyfitriani44@gmail.com } \\ \text { Address } & \text { : Program Studi Kriya Tekstil, Fakultas Seni Rupa dan Desain, Universitas } \\ & \text { Sebelas Maret Indonesia }\end{array}$




\section{Pengembangan Desain Batik Limbah Grajen di Bulakan Sukoharjo, Jawa Tengah}

Fify Fitriani, Setyawan

\section{PENDAHULUAN}

Sukoharjo merupakan salah satu kabupaten di Jawa Tengah yang dekat dengan Kota Surakarta, secara historis wilayah Sukoharjo adalah salah satu kawasan Karisedenan Surakarta. Kabupaten Sukoharjo secara administratif memiliki 12 Kecamatan, yang memiliki 17 kelurahan, dan 150 desa. Salah satunya adalah Bulakan yang berada di Kecamatan Sukoharjo, Kabupaten Sukoharjo.

Sukoharjo memiliki sejarah perkembangan batik yang cukup lama, hingga sukoharjo menjadi salah satu daerah induk batik tulis di Surakarta. Perkembangan batik di sukoharjo berawal dari merosotnya batik istana yang terjadi pada tahun 1930-an sampai 1960-an. Hal ini dapat dilihat pada daerah-daerah sumber batik, yang saat itu merupakan daerah induk batik di Surakarta.

Batik yang berkembang di wilayah Sukoharjo merupakan hasil pengembangan dari batik keraton (pola keraton) maupun batik yang menggambarkan sebuah pola yang terinspirasi dari lingkungan sekitar (pola pedesaan). Pengembangan pola tersebut dipengaruhi oleh profesi masyarakat Sukoharjo yang bekerja sebagai petani, menyebabkan para pembatik di Sukoharjo menggunakan kedua pola tersebut.

Perkembangan batik di Sukoharjo, memiliki kaitan dengan kondisi masyarakat sebagai cermin kondisi budaya yang terjadi pada setiap daerah pada saat perkembangan batik terjadi seperti halnya pada batik yang berkembang di Bulakan Sukoharjo yang terpengaruh oleh kondisi lingkungan sekitar para pembatik untuk membuat batik kreasi baru yang sesuai dengan kondisi lingkungan sekitar pengrajin batik yang merupakan salah satu sentra furniture terbesar di Jawa Tengah.

Kondisi lingkungan pengrajin yang terdapat banyak limbah grajen (serbuk kayu) menyebabkan para pengrajin berinisiatif untuk memanfaatkan limbah grajen tersebut menjadi pewarna alam. Pemanfaatan limbah grajen menjadi pewarna alam yang digunakan untuk pembuatan batik kreasi baru di Sukoharjo adalah pewarna alam yang ramah lingkungan sehingga mengurangi tingkat pencemaran pewarna sintetis (down to earth) sebab pewarna alam yang dihasilkan dari limbah grajen mampu diserap oleh alam, dan menggurangi limbah yang ada di lingkungan sekitar para pembatik.

Batik limbah grajen memiliki potensi yang sangat besar, batik grajen dapat menjadi ikon dari daerah Bulakan maupun Kabupaten Sukoharjo yang belum memiliki ciri khas tersendiri di dalam batik yang dibuat baik dari segi pewarnaan maupun dari segi desain. Peluang pasar untuk konsep pengembangan desain batik limbah grajen sangat besar dikarenakan tidak setiap produsen batik maupun pengrajin batik yang membuat motif batik yang menggambarkan bagaimana ciri khas dari sebuah daerah, dan tidak semua pengrajin batik menggunakan limbah grajen kayu sebagai bahan unutk pewarna pada kain batik yang pengrajin produksi. Batik grajen juga dapat menjadi ikon sehingga menarik minat wisatawan untuk mendatangi Bulakan untuk melihat proses pembuatan batik.

Batik limbah grajen perlu dikembangkan lebih lanjut terutama dalam segi desain dikarenakan batik limbah grajen memiliki potensi yang cukup besar di dalam pewarnaan yang di lakukan pada batik yang dibuat oleh para pengrajin, akan tetapi di dalam segi desain batik limbah grajen memiliki desain yang sama dan kurang berkembang semenjak 
para pembatik melakukan pembatikan di wilayah Bulakan, desain merupakan roh yang menggambarkan sebuah daerah, hingga menjadi ciri khas dari daerah tersebut dan membedakan dari daerah lain.

Penelitian mengenai limbah grajen yang digunakan untuk pewarna pada batik belum pernah dilakukan sebelumnya akan tetapi ada peneliti yang melakukan penelitian mengenai limbah kayu yang digunakan sebagai bahan pewarna alam untuk batik. Penelitian mengenai limbah serutan kayu pernah dipublikasikan dalam bentuk jurnal, seperti yang dilakukan oleh Agus Haerudin dan Farida pada tahun 2017 yang berjudul "Limbah Serutan Kayu Matoa (Pometia Pinnata) sebagai zat warna alam pada kain batik Katun". Penelitian tersebut melakukan eksperimen serta membahas mengenai potensi limbah sumber daya alam di Indonesia khususnya limbah kayu-kayuan sangat melimpah salema ini pemanfaatannya belum optimal dan belum memiliki nilai jual yang tinggi. Salah satunya adalah serutan kayu matoa. Penelitian ini merupakan eksperimen pembuatan ekstrak zat warna alam dari limbah serutan kayu matoa yang diaplikasikan pada kain batik katun [1].

Motif batik yang berkembang di pengrajin batik limbah grajen dipengaruhi oleh kaumkaum saudagar batik yang mengembangkan motif-motif batik yang berasal dari keraton dengan menambahkan beberapa hal baik itu membesarkan ukuran motif batik tersebut atau membedakan warna pada batik yang mereka buat, sehingga memiliki motif yang sedikit berbeda dengan motif motif yang menjadi motif larangan pada batik keraton.

Batik limbah grajen yang berkembang di Bulakan memiliki spesialisasi di dalam pembuatan batik parang, kawung, kopi pecah, serta tirtotejo. Desain untuk motif-motif tersebut sangatlah banyak di pasaran, hampir setiap pengrajin batik membuat motif-motif tersebut. Sehingga dari motif-motif yang dihasilkan belum menunjukan ciri khas dari batik limbah grajen di Bulakan.

Desain merupakan sebuah unsur penting dari sebuah motif hal ini dikarenakan desain merupakan sebuah nyawa yang menggambarkan suatu tempat ataupun keadaan tertentu, desain dapat menjadi sebuah pembeda dari batik daerah satu dengan daerah lain dikarenakan didalam selembar kain batik mampu mengangkat sebuah peristiwa dari sebuah daerah.

Pengembangan mengenai desain batik daerah pernah dilakukan dalam beberapa penelitian seperti yang dilakukan oleh Ana Irhandayaningsih pada tahun 2017 yang berjudul "Pengembangan Motif Batik Temanggung Melalui Penguatan Ciri Visual Bertema Kopi". Penelitian tersebut bertujuan untuk mengembangkan motif batik dengan ciri khas ornamen visual berupa tanaman kopi disetiap motifnya dengan membuat motif batik yang lebih bervariasi, dan mengembangkan ornament dan biji kopi dari beberapa batik Temanggung khususnya di pengrajin "batik Lumbung" [2].

Penelitian yang dilakukan oleh Triyono Widodo dan ponimin juga melakukan pengembangan desain batik daerah yang diberi judul "Desain Produk Batik Sentra Pringen Lereng Gunung Welirang Artistik dan Berkarkter". Penelitian tersebut berisi mengenai pengembangan motif hias batik khas daerah dengan alam tumbuhan di kawasan lereng gunung Welirang kabupaten Pasuruan yang terdiri dari beragam bentuk, akan tetapi pengrajin batik di daerah tersebut tidak memahami cara mengembangkan potensi alam menjadi ragam motif batik [3].

Batik dari pewarna alam limbah grajen merupakan sebuah hal yang menarik untuk dikembangkan akan tetapi apabila tidak diimbangi dengan perupaan (visual) motif yang menjadi ikon dari daerah tempat berkembangnya batik limbah grajen. Berdasarkan pengalan-pengalan fakta di atas maka di dalam penelitian ini akan mengkaji lebih jauh mengenai batik limbah grajen yang berkembang di Bulakan pada era sekarang yang akan 
dikaji dengan pendekatan etnografi, yakni model penelitian yang mendeskripsikan kebudayaan sebagaimana adanya. Seperti yang diungkapkan oleh Bronoslaw Malinowski, bahwa pendekatan etnografi berupaya untuk "memahami sudut pandang penduduk asli, hubungan dengan kehidupan, untuk mendapatkan pandangan mengenai dunia". Penelitian etnografi juga melibatkan aktifitas belajar melihat, mendengar, berbicara, berpikir, dan bertindak dengan cara yang berbeda. Jadi etnografi tidak hanya mempelajari masyarakat, tetapi lebih dari itu, etnografi belajar dari masyarakat [4].

Menangkap peluang lain dari hal di atas, penelitian ini juga dapat melakukan pengembangan desain batik di Bulakan Sukoharjo dengan mempertimbangkan dari peluang membuat produk baru yang berfokus pada pengolahan visual (motif). Ide visual yang ditawarkan adalah batik yang sudah menjadi spesialisasi pengrajin dengan ciri khas yang ada di Bulakan seperti kayu d.I.I. sehingga menghasilkan visual yang baru dan dapat menjadi ciri khas dari batik Bulakan serta menjadi penguat nilai dari produk batik tulis serta dapat menjadikan batik yang dihasilkan lebih bernilai dibandingkan dengan produk yang lainnya.

\section{METODE PENELITIAN}

Penelitian ini dilakukan untuk menjawab masalah-masalah yang ada, maka rancangan teori atau kerangka pikir menggunakan metode action research atau kaji tindak. Yang merupakan salah satu metode untuk memperoleh pengetahuan sekaligus melakukan tindakan untuk menciptakan perubahan di dalam masyarakat. Penelitian tindakan merupakan penelitian yang menjadi sebuah alternatif dalam melakukan penelitian.

Penelitian tindakan difokuskan kepada hadirnya pengetahuan melalui tindakan, data dipadukan dan diinterpretasikan secara kontekstual. Dasar pelaksanaan penelitian tindakan bersandar pada asumsi epistimologis yang menyatakan bahwa tujuan penelitian tindakan bersandar pada asumsi epistimologis yang menyatakan bahwa tujuan penelitian dan wawancara akademik bukan hanya mendeskripsikan, memahami, dan menjelaskan keadaan dunia, melainkan bagaimana mengubahnya. Penekananya bukan hanya sekedar menghasilkan pengetahuan dan menggunakan metodologi untuk mengumpulkan data, melainkan juga siapa yang memutuskan agenda penelitian dan siapa juga yang mendapatkan keuntungan dari hasil penelitian tersebut.

Mempertimbangkan batik limbah grajen sebagai teks maka rancangan teori yang dipakai dalam penelitian ini adalah etnografi dimana pendekatan ini memandang kehidupan masyarakat di Bulakan, dengan menyoroti aspek-aspek budaya yang ada. Etnografi sendiri merupakan bagian dari kajian antropologi yang tujuan utamanya adalah memahami suatu pandangan hidup dari sudut pandang penduduk asli atau masyarakat yang diteliti [4].

Lewat kajian etnografi maka batik limbah grajen akan dikaji dari sisi kebudayaan masyarakat pendukungnya, yakni masyarakat desa Bulakan. Pendekatan etnografi dipakai dalam penelitian, dapat mengeksplorasi bagaimana batik limbah grajen sebagai produk budaya adalah saling berkaitan dengan makna yang berhubungan dengan realisasi sosial, praktek dan pengalaman masyarakat alam antropologi seni yang sering dipakai dalam mengkaji fenomena kesenian adalah pendekatan kontekstual. Pendekatan ini untuk memehami fenomena kesenian secara holistic atau menyeluruh agar si pengkaji seni atau peneliti dapat melihat kesenian menjadi lebih utuh.

Mengingat penelitian ini merupakan kaji tindak yang melibatkan perancangan pengembangan desain batik limbah grajen, maka perancangan pengembangan desain di dalam pengembangannya menggunakan metode desain yang melewati 3 proses utama yakni (1) proses eksplorasi, proses analisis yang bersifat pendalaman, penelusuran, atau pengalian atas sejumlah hal. (2) proses ekstraksi yaitu proses analisis yang bersifat rangkuman, ekstraksi dan pembuatan kesimpulan atas sejumlah hal. (3) titik terminasi, 
suatu titik yang mewakili kondisi awal saat akan memulai suatu kegiatan. Bentuk kegiatan pada titik terminasi berupa perencanaan kegiatan, evaluasi dan melihat kembali, dan presentasi. Tiga tahapan proses desain tersebut kemudian dijabarkan dalam empat langkah operasional, yakni : (1) proses analisis desain dan penetapan target perencanaan. (2) proses analisis aspek desain dan penyusunan konsep desain. (3) proses penjabaran konsep dan pembuatan desain (visualisasi). (4) proses tes produk [5].

Batik merupakan sebuah ciri khas dari suatu daerah, yang memiliki kaitan dengan keadaan masyarakat sebagai cermin budaya yang terjadi pada setiap daerah pada saat perkembangan sosial budaya daerah tersebut. Seperti halnya pada batik yang berkembang di Bulakan Sukoharjo, yang terpengaruh oleh kondisi lingkungan sekitar para pembatik untuk membuat batik kreasi baru sesuai dengan kondisi lingkungan yang ada di sekitar para pengrajin.

Batik di Bulakan berbeda dari batik yang berasal dari daerah lain, hal ini dikarenakan lingkungan pembatik yang hidup di tengah-tengah salah satu sentra industri furniture terbesar di Jawa Tengah, menyebabkan para pembatik memiliki ide untuk mengembangkan batik dengan pewarna alam yang berasal dari limbah grajen yang banyak terdapat di desa Bulakan.

Limbah grajen yang banyak membuat para pengrajin batik membuat batik dengan pewarna alam limbah grajen. Berbeda dengan daerah lain di dalam penggunaan pewarna alam, biasanya menggunakan pewarna alam yang sudah tersedia di pasaran, sedangkan pembatik di bulakan memanfaatkan apa yang ada di lingkungan sekitar para pembatik sehingga memiliki ciri khas tersendiri dari bahan dasar pembuatan pewarna alam yang digunakan.

\section{PERMASALAHAN DESAIN BATIK LIMBAH GRAJEN}

Motif yang berkembang di desa Bulakan hampir $85 \%$ merupakan motif-motif geometris, yang merupakan pengembangan dari motif-motif keraton. Batik di Bulakan cenderung memiliki desain dan warna yang menggarah ke pada keraton Surakarta yang menggunakan latar gelap pada kain batik yang dibuat. Desain yang lain berupa desaindesain Buketan dengan hewan dan sekar jagad yang bentuknya tidak menyerupai bentuk asli dari hewan tersebut, hal ini dikarenakan para pembatik di Bulakan memiliki keyakinan yang sangat kuat mengenai kepercayaan agama yang mereka anut bahwa tidak boleh menggambarkan bentuk makhluk hidup secara nyata, menyebabkan tidak semua pembatik mau membuat batik yang mengandung unsur-unsur hewan yang ada di dalam kain batik tersebut.

Pembuatan motif yang hanya berputar pada motif-motif itu saja suatu saat akan menimbulkan sebuah masalah, karena di dalam perkembangan industri batik motif akan selalu berkembang seiring dengan berjalannya waktu. Hal ini juga diungkapkan oleh bu Darsono bagaimana sulitnya untuk memasarkan produk yang dibuatnya, baik itu batik mentahan maupun batik grajen, karena kendala motif yang dibuat oleh Bu Darsono kurang memiliki ciri khas seperti yang ada di daerah-daerah lain, serta ukuran motif yang besar menyebabkan apabila kain tersebut di jadikan pakaian akan mengalami mengalami kesulitan dikarenakan motif dari batik tidak begitu terlihat. Serta kurangnya pengetahuan mengenai pembuatan desain batik, serta sulitnya pembatik untuk membuat motif lain agar dapat bersaing dengan industri batik yang lain di dalam motif.

Kain yang pengrajin buat rata-rata adalah kain -kain yang memiliki bentuk geometris, di dalam melakukan pengarisan untuk membuat pola geometris tersebut para pengrajin tidak melakukan penghitungan ukuran, pengrajin hanya sekedar mengaris saja, menyebabkan motif kain yang dihasilkan dapat memiliki ukuran yang berbeda-beda, dan kain batik yang memiliki motif miring sehingga sulit untuk dijadikan produk lainnya. 
Kurangnya pengetahuan pembuatan motif tersebut juga diungkapkan oleh Bu Darsono selaku pengrajin batik limbah grajen.

Motif yang dibuat oleh para pengrajin batik di Bulakan juga kurang memperhitungkan bagaimana desain kain batik yang dapat digunakan menjadi pakaian atau fungsi yang lainnya. Hampir sebagian besar kain batik yang diproduksi oleh pembatik di desa Bulakan sulit untuk dibuat menjadi sebuah pakaian, dikarenakan motif yang dibuat terlalu besar sehingga apabila dibuat menjadi pakaian motif batik tersebut tidak begitu nampak keseluruhan, hanya bagian bagian tertentu saja yang dapat terlihat di dalam pakaian yang dibuat. Kain yang memiliki ukuran motif yang besar sulit untuk digunakan menjadi barang apapun, untuk menjadi pakaian akan terlihat kurang menarik karena motif yang terlalu besar sehingga motif tidak telihat utuh. Ada beberapa bagian kain yang terpotong serta tidak sesuai dengan sangitan apabila digunakan. Kain bermotif besar untuk digunakan menjadi jarik pun juga akan kurang menarik dengan motif yang terlalu besar.

Selain batik yang memiliki motif terlalu besar, di dalam pembuatan batik grajen yang memiliki motif-motif geometris di dalam pembuatan garisnya tidak melalui pengukuran agar semua garis dasar yang dibuat untuk motif tersebut memiliki ukuran sama besar. Menyebabkan ada beberapa bagian dari motif yang memiliki ukuran yang lebih kecil atau lebih besar dari ukuran motif yang lain. Hal ini menyebabkan kesulitan apabila kain batik tersebut dibuat untuk menjadi sebuah pakaian maka pakaian yang dihasilkan tidak memiliki sambungan motif yang sesuai.

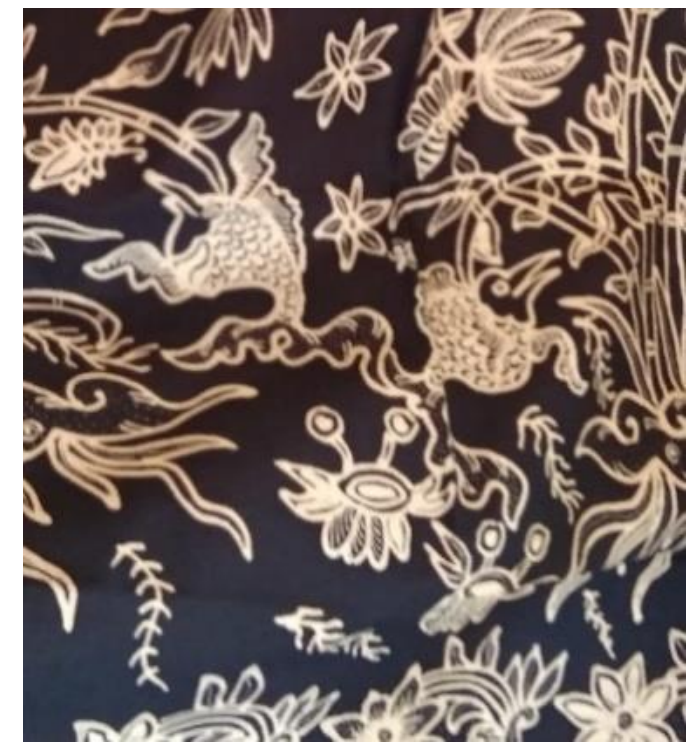

Gambar 1 Buketan, 2019, tekstil, 2400 x 1150 $\mathrm{cm}$, koleksi Batik Sari Rejeki

Batik di Bulakan terkenal dengan motif parang dan kawung yang luwes bahkan pembatik di daerah tersebut dapat membuat batik dengan motif parang dan kawung tanpa digambar atau coretan pensil yang membentuk gambar dari parang dan kawung, dan para pembatik langsung bisa mengerjakan proses pembatikan tersebut. Meskipun demikian ada kelemahan didalam proses pembatikan yang ada di Bulakan.

Hingga saat ini pengrajin batik yang ada di Bulakan, hanya membuat motif-motif tersebut tanpa sebuah upaya untuk mengembangkan motif yang para pembatik buat. Banyak hal yang mempengaruhi kenapa pembatik di Bulakan kurang memiliki upaya untuk mengembangkan motif batik yang pengrajin buat.

Kurangnya upaya dalam pengembangan motif di Bulakan dipengaruhi oleh beberapa hal, seperti para pembatik yang berada di Bulakan sebagian besar menganut agama Islam 
dalam keyakinan yang mereka yakni melarang untuk membuat gambar yang mengambarkan bentuk makhluk hidup, sehingga hampir keseluruhan pembatik tidak mau membuat batik yang memiliki motif makhluk hidup, hanya satu, dua orang pembatik yang mau membuat batik yang memiliki motif makhluk hidup misalkan pada sebuah motif buketan yang memiliki motif ikan di dalamnya dan motif ikan yang dibuat pun mengalami perubahan bentuk stilasi secara signifikan.

Setiap pembatik yang ada di Bulakan tidak semuanya bisa mengerjakan seluruh motif batik yang sudah menjadi spesialisasi di Bulakan dalam membuat motif kawung; parang; kopi pecah dan tirto tejo, tetapi ada beberapa motif yang tidak bisa dikerjakan oleh sembarangan pembatik yang ada di Bulakan. Misalnya, seperti pada motif parang modang, tidak semua pembatik bisa mengerjakan motif tersebut, hanya ada dua pembatik saja di Bulakan yang bisa membuat motif parang modang.

\section{POTENSI}

Batik limbah grajen memiliki potensi yang cukup besar dalam perkembangannya, hal ini dikarenakan batik limbah grajen dapat menjadi ikon dari daerah Bulakan maupun Kabupaten Sukoharjo yang belum memiliki ciri khas tersendiri didalam batik yang dibuat baik dari segi pewarnaan maupun dari segi desain yang ada di Sukoharjo maupun Bulakan. Motif Batik yang ada di Sukoharjo merupakan pengembangan motif batik yang sudah ada sebelumnya dari wilayah Surakarta.

Peluang pasar untuk pengembangan konsep desain batik limbah grajen cukup besar dikarenakan tidak setiap produsen batik maupun pengrajin batik yang membuat motif batik yang menggambarkan bagaimana ciri khas dari wilayah tempat tinggal pengrajin, serta tidak semua pengrajin batik menggunakan limbah grajen kayu sebagi bahan pewarna alamnya sehingga peluang untuk mengembangkan desain batik grajen cukup besar dalam penjualan dipasaran. Perkembangan batik limbah grajen juga dapat menarik wisatawan untuk datang ke daerah Bulakan untuk melihat batik limbah grajen serta melihat proses pembuatan batik limbah grajen.

\section{PENGEMBANGAN DESAIN}

Batik grajen perlu dikembangkan dikarenakan batik grajen memiliki bahan pewarna alam yang berbeda dari pewarna alam yang lainnya, pewarna alam yang digunakan di dalam batik grajen berasal dari limbah serbuk kayu atau grajen yang berada dilingkungan para pengrajin batik yang ada di desa Bulakan.

Setiap saudagar dan pembatik di sautu daerah memiliki spesialisasi yang beranekaragam di dalam pembuatan batik yang mereka buat, seperti halnya di Bulakan yang juga memiliki spesialisasi di dalam pembuatan batik parang; Kawung; kopi pecah serta Tirtotejo. Sedangkan untuk desain dari motif-motif tersebut antara banyak di pasaran dan banyak pengrajin yang menggunakan motif tersebut.

Pengrajin batik di Bulakan telah mengembangkan pewarnaan alam dari limbah grajen yang menjadi ikon dari batik Sari Rejeki dan Tri Rejeki yang ada di Bulakan, akan tetapi batik Grajen memiliki desain yang banyak terdapat di pasaran, menyebabkan motif batik yang dibuat di Bulakan belum menunjukan ciri khas Bulakan. Desain sangat penting, hal ini dikarenakan desain merupakan sebuah nyawa yang mengantarkan suatu tempat ataupun keadaan tertentu, desain sendiri dapat menjadi pembeda dari batik daerah yang satu dengan batik yang ada di daerah yang lain.

Batik dari limbah grajen merupakan hal yang sangat menarik untuk dikembangkan. akan tetapi, apabila tidak diimbangi dengan desain yang menjadi ikon suatu daerah maka hal tersebut juga akan mempengaruhi penjualan batik tersebut untuk membedakan daerah yang satu dengan daerah yang lain, maka dari hal tersebut akan menimbulkan 
sebuah masalah apabila desain dari batik limbah grajen tersebut tidak dikembangkan dengan menunjukan ciri khas yang ada di Bulakan.

\section{Konsep Desain}

Konsep perancangan desain batik grajen adalah bagaimana memvisualisasikan hal-hal yang ada di Bulakan baik dari segi kayu-kayuan yang digunakan sebagai bahan dasar produksi mebel, serta batik yang menjadi ciri khas di Bulakan.

Perancangan ini memadukan hal-hal yang menjadi ciri khas yang ada di Bulakan dengan tidak melepaskan kebaiasaan pembatik dan kepercayaaan yang pembatik percayai. Dari perpaduan tersebut dapat menjadikan kekuatan desain yang memiliki nilai pembeda (diferensiasi produk) yang tinggi dibandingkan dengan produk batik tulis yang lain yang sudah ada di pasaran, dan menimbulkan ciri khas tersendiri bahwa desan batik yang dibuat merupakan batik yang berasal dari Bulakan dengan pewarna alam limbah grajen.

Gaya atau karakter yang kuat dari perancangan desain ini adalah dari segi visualnya, yaitu mengusung visual yang menjadi ciri khas para pembatik di Bulakan kerjakan seperti motif parang, kawung, kopi pecah dan tirtotejo, yang memiliki kekuatan garis-garis yang ritmis serta pengulangan komposisi gambar maupun garis yang rumit, dipadukan dengan alur garis menyerupai garis-garis yang terdapat pada lingkaran tahun kayu.

Konsep desain ini diharapkan agar desain batik yang dibuat memiliki ruh (nyawa) yang menggambarkan dan sesuai dengan kondisi budaya pengrajin batik limbah grajen. Hingga memiliki ciri khas tersendiri di dalam desain yang pengrajin buat selain dalam pembuatan pewarna alam.

\section{Gagasan Pengembangan Desain Batik Limbah Grajen}

Motif-motif yang memiliki potensi untuk dikembangkan di Bulakan tidak mungkin lepas dari motif-motif yang selama ini pengrajin buat seperti motif parang, kawung, tirtotejo dan kopi pecah, apabila pengembangan motif yang terlalu signifikan dan keluar dari kebiasaan para pembatik membuat batik, dapat menyebabkan motif baru yang dibuat kesulitan untuk di produksi, dari hal tersebut apabila ingin membuat motif yang baru sesuai dengan ciri khas yang ada di Bulakan tidak dapat melepaskan motif-motif yang sudah sering dikerjakan oleh pembatik.

Pengembangan desain untuk batik grajen lebih mengedepankan di dalam segi visual dan teknik di dalam pembatikan batik, untuk sistem dan konsep di dalam pembuatan visual kurang begitu di perhitungkan karena para pengrajin batik kurang memperhatikan apa makna yang terkandung di dalam batik tersebut. Pengrajin batik lebih menggutamakan bentuk visual yang menarik sehingga dapat menarik minat pembeli dan proses produksi kain batik yang mereka jual dapat berjalan dengan lancar.

Desa Bulakan tidak memiliki ciri khas yang menonjol di dalam kekhasan flora dan fauna akan tetapi hampir setiap warga yang ada di Bulakan membuat furniture dan kayu merupakan bagian dari kehidupan warga Bulakan, Kayu memiliki bentuk alur yang menarik tergantung dari mana sisi kita melihat kayu tersebut dan setiap kayu memiliki ciri khas masing-masing di dalam alur yang dihasilkan dari lingkaran tahun kayu. Kayu yang banyak di produksi di sentra mebel yang ada di desa Bulakan adalah kayu Mahoni, Mindi dan Kayu Jati (Lawasan).

\section{Selera Konsumen}

Menurut Bu Darsono untuk permintaan kain batik yang selama ini beliau jual lebih banyak konsumennya yang tertarik kepada motif-motif parang, Kawung, kopi pecah dan 
Tirtotejo. Motif-motif yang lain seperti hewan pembeli dari batik Bu Darsono kurang memiliki peminat dan pembatik dari Bu Darsono. Kurangnya peminat terhadap motifmotif tersebut juga di dukung dengan kepercayaan masyarat setempat di dalam pembuatan motif-motif hewan bahwa tidak diperbolehkan untuk mengambarkan hewan secara nyata atau menyerupai bentuk asli dari hewan tersebut. Menyebabkan sedikitnya pembatik yang berkenan untuk membuat batik dengan motif hewan.

Industri rumahan Batik grajen milik Bu Darsono dapat memproduksi hingga 200 potong kain batik mentahan dalam waktu 1 (satu) minggu dengan pembeli dari beberapa daerah di Indonesia seperti Surakarta, Jakarta dan Bali. Sebagian dari kain batik mentahan ada yang dijual secara mentahan untuk industri batik lain ada juga yang di proses lebih lanjut dengan menggunakan pewarna alam limbah grajen. Dengan target pasar untuk penjualan batik adalah orang-orang menengah hingga menengah keatas, dikarenakan batik yang dibuat oleh Bu Darsono adalah batik tulis dan dengan pewarnaan alam. Hal ini tergantung dengan permintaan konsumen. Bu Darsono menjual batiknya hanya dalam berupa lembaran kain jarik sehingga target pasarnya bisa mencakup berbagai macam usia serta gender.

\section{Harga Produk dan Harga Jual}

Harga produk dan harga jual sangat berpengaruh terhadap konsumen yang akan membeli barang yang telah diproduksi, manakah target pasar yang akan dituju hal ini dikarenakan tidak setiap kalangan dapat membeli suatu produk dikarenakan konsumen pasti berasal dari tingkat ekonomi yang berbeda.

Produk batik limbah grajen yang akan dibuat memiliki harga yang tinggi dikarenakan menggunakan teknik batik tulis dengan pewarna limbah grajen kayu menyebabkan target konsumen untuk membeli batik grajen memiliki target konsumen menengah atau menengah ke atas dikarenakan harga jual dari kain batik tersebut yang tinggi.

Akan tetapi batik yang dijual memiliki nilai keeksklusifan tersendiri dikarenakan proses pembatikan tulis yang di dalam pengerjaannya memiliki perbedaan dari satu kain dengan kain yang lain. Serta dari pewarna limbah grajen yang memiliki warna dengan hasil yang berbeda beda tergantung kepada limbah kayu apa yang digunakan untuk proses pewarnaan.

\section{Teknik Produksi}

Batik limbah Grajen dibuat dengan teknik batik tulis yang merupakan teknik yang pertama kali muncul serta memiliki keeksklusifan tersendiri dalam pembuatannya. Sedangkan untuk pewarna yang digunakan didalam batik Grajen adalah pewarna yang berasal dari limbah grajen atau serbuk kayu yang banyak terdapat dilingkungan sekitar tempat tinggal pengrajin batik yang ada di desa Bulakan Sukoharjo.

Proses pemberian warna untuk batik Grajen adalah proses pembatikan tutup celup sebagai perintang. Proses pembuatan warna limbah grajen yang dibuat cukup panjang dikarenakan kayu yang dibuat sebagai bahan pewarna berasal dari limbah kayu yang sudah mengalami proses pengovenan sehingga warna yang terkandung di dalam kayu sudah mengering. Menyebabkan proses pengekstrakan sangat memakan waktu yang cukup lama, untuk perendaman kayu ke dalam air hampir mencapai waktu 24 jam, dan untuk perebusan warna mencapai 24 jam dengan mengunakan limbah kayu sebagai bahan bakar perebusan.

Proses pencelupan kain batik kedalam pewarna alam tidak dapat diperkirakan berapa kali proses pencelupan yang dilakukan, karena warna yang dihasilkan di dalam proses ekstraksi memiliki tingkat kekuatan yang berbeda-beda setiap proses pengekstrakan warna yang dilakukan. Menyebabkan kain batik yang dihasilkan memiliki warna yang berbeda-beda antara kain batik yang satu dengan kain batik yang lainnya. 


\section{Desain}

Desain batik yang berkembang di Bulakan adalah batik yang memiliki motif dari kembangan motif-motif paten yang ada di keraton seperti motif parang dan Kawung. Parang dan Kawung dalam perkembangannya banyak pengrajin batik yang membuat motif tersebut hingga perkembangan desain batik limbah grajen pun minim, serta kurang menunjukannya ciri khas dari batik yang ada di Bulakan, tidak seperti batik-batik yang ada di wilayah lain yang dapat menunjukan ciri khas dari batik yang ada di wilayah mereka.

Batik di Bulakan juga memiliki beberapa kelebihan dan kelemahan di dalam desain batik yang pengrajin kerjakan. Kelebihan dari desain batik limbah grajen Bu Darsono adalah motif parang, Kawung, kopi pecah, dan Tirtotejo merupakan motif-motif yang tidak akan pernah punah seiring dengan perkembangan jaman, Baik itu dari jaman dahulu maupun di jaman yang akan datang dikarenakan motif-motif tersebut merupakan motifmotif pakem yang dikembangkan di lingkungan luar keraton.

Kelemahan dari desain batik yang ada di Bulakan yang dilakukan pengrajin di dalam pembuatan motif yang pengrajin buat kurang memperhitungkan beberapa hal agar kain batik yang diproduksi dapat memiliki fungsi lain, selain sebagai jarik maupun koleksi pribadi saja, banyak dari kain batik yang pengrajin batik produksi memiliki ukuran motif yang cukup besar.

Kain yang pengrajin buat rata-rata adalah kain - kain yang memiliki bentuk geometris, dalam melakukan pengarisan untuk membuat pola geometris tersebut para pengrajin tidak melakukan penghitungan ukuran, pengrajin hanya sekedar mengaris saja sehingga menyebabkan motif kain yang dihasilkan dapat memiliki ukuran yang berbeda-beda, dan kain batik yang memiliki motif miring sehingga sulit untuk dijadikan produk lainnya.

Kurangnya pengetahuan pembuatan motif tersebut juga diungkapkan oleh Bu Darsono, beliau ingin motif batik yang diproduksi juga berkembang, tidak hanya membuat motif-motif itu saja melainkan juga bagaimana agar desain dari kain batik yang Bu Darsono buat juga bisa dimanfaatkan pengunaannya lebih luas lagi, dengan kain batik yang lebih baik dan pengunaan yang lebih luas bu Darsono juga berharap agar peminat kain batik lebih banyak serta produksi yang dilakukan bu Darsono semakin lancar.

Desain batik grajen perlu dikembangkan dan diperbaiki dari segi desain dikarenakan di dalam proses pembuatan motif para pengrajin di Bulakan kurang memperhitungkan bagaimana desain kain batik yang dapat digunakan menjadi pakaian atau fungsi yang lainnya. Hampir sebagian besar kain batik yang diproduksi oleh pembatik di Bulakan sulit untuk dibuat menjadi sebuah pakaian, dikarenakan motif yang dibuat terlalu besar sehingga apabila dibuat menjadi pakaian motif batik tersebut tidak begitu nampak keseluruhan, hanya bagian bagian tertentu saja yang dapat terlihat di dalam pakaian yang dibuat tersebut.

Kain yang memiliki desain motif terlalu besar jarang memiliki minat dipasaran, hanya orang-orang tertentu saja yang ingin membeli kain tersebut hanya digunakan utnuk koleksi pribadi. Kurangnya peminat kain yang memiliki motif besar menyebabkan kain yang dijual oleh Bu Darsono pun tidak begitu lancar penjualannya untuk kain batik yang memiliki motif besar. Tetapi apabila motif kain yang terlalu kecil para pembatik di Bulakan enggan untuk mengerjakan motif tersebut.

Selain batik yang memiliki motif terlalu besar, di dalam pembuatan batik grajen yang memiliki motif-motif geometris di dalam pembuatan garisnya tidak melalui pengukuran agar semua garis dasar yang dibuat untuk motif tersebut memiliki ukuran sama besar. Menyebabkan ada beberapa bagian dari motif yang memiliki ukuran yang lebih kecil atau lebih besar dari ukuran motif yang lain. Hal ini menyebabkan kesulitan apabila kain batik 
tersebut dibuat untuk menjadi sebuah pakaian maka pakaian yang dihasilkan tidak memiliki sangitan yang pas.

\section{Visualisasi}

Visualisasi pada proyek pengembangan desain ini mengolah unsur-unsur yang ada di dalam visual kain batik yang sudah lama dikerjakan oleh pengrajin yang ada di desa Bulakan (parang, kawung, kopi pecah, tirtotejo, dll.). unsur-unsur tersebut diolah dengan memadukan ciri khas yang ada di desa Bulakan (kayu dan jeruk nipis). Alasan pemilihan pengabungan kedua hal tersebut sebagai sumber ide desain batik grajen. Pertama, untuk memberikan warna yang baru pada dunia batik dengan memberikan visual batik grajen yang sesuai dengan ciri khas daerah sehingga nyawa yang terkandung di dalam batik grajen lebih timbul lagi. Kedua, mengadaptasikan batik yang bisa diterima oleh pengrajin batik maupun pembeli batik grajen.

Secara visual, batik grajen menggolah desain yang sudah sering dikerjakan oleh pengrajin batik yang ada di desa Bulakan dengan hal-hal yang menjadi ciri khas desa Bulakan, sehingga menjadi komposisi desain yang menarik. Segi pewarnaan desain batik grajen tidak dapat bervariasi hal ini dikarenakan viksator dan pewarna yang digunakan yang berasal dari alam.

Salah satu hasil visualisasi dari desain yang dikembangkan untuk batik grajen ini akan dilakukan proses produksi secara berkelanjutan, sebagai ciri khas batik grajen, diharapkan agar desain yang memiliki nyawa tersebut dapat menjadi ciri khas yang mengangkat tempat berkembangnya batik grajen.

\section{Pemecahan Visual}

Tabel 1 Pemecahan visual isen-isen

\begin{tabular}{lll}
\hline No & Foto & Pemecahan Visual
\end{tabular}
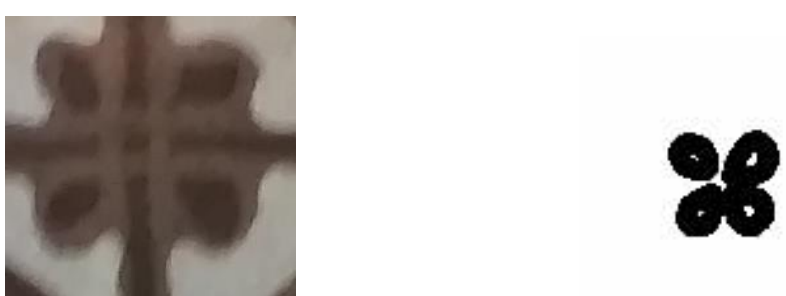

Isen-isen Kopi pecah, 2019 


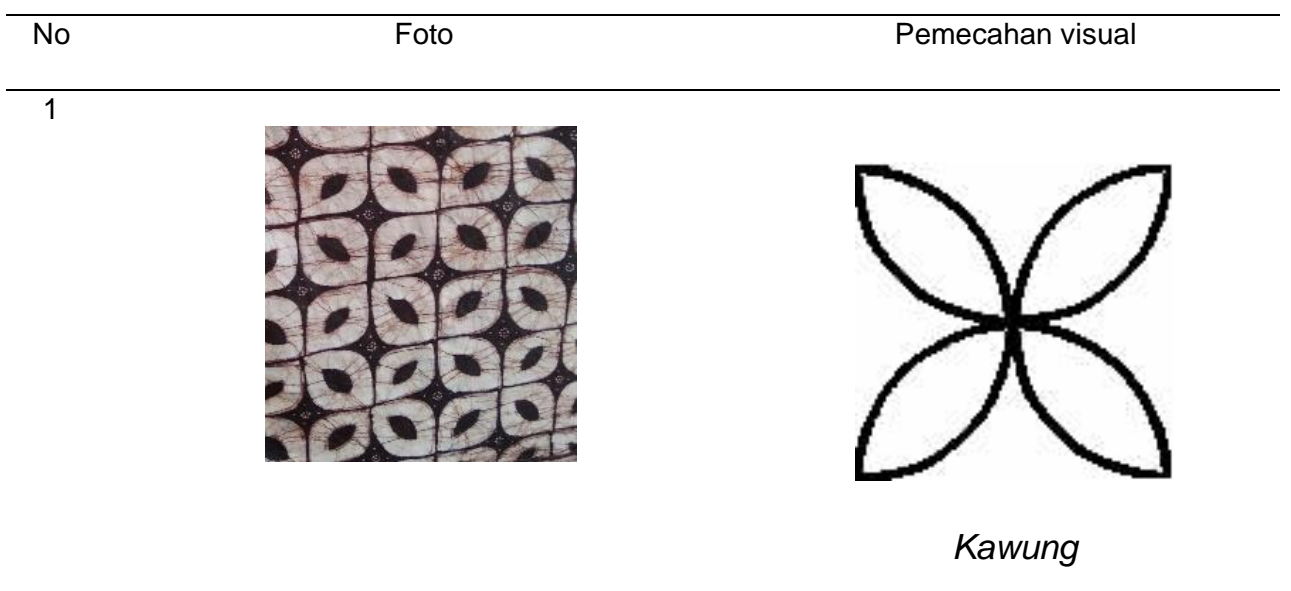

2
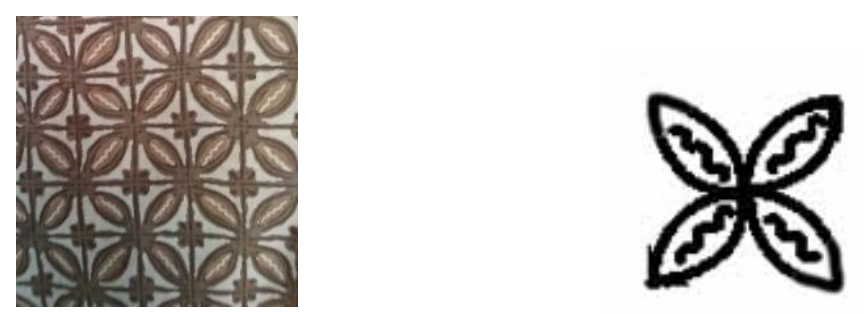

Kopi pecah

3
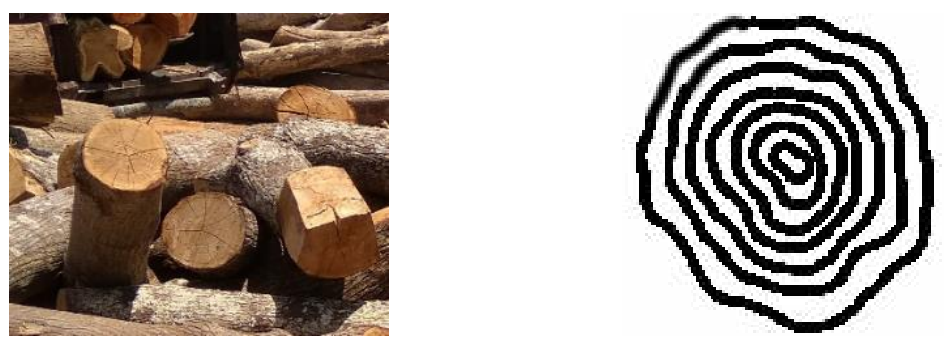

Lingkaran Tahun kayu

\section{Pengembangan Visual (Desain)}

Desain batik grajen kawung kayu merupakan pengembangan desain dari batik kawung yang sudah ada dan di produksi oleh pengrajin. Desain batik Kawung yang terlalu polos dan motif yang dihasilkan terlalu besar, sehingga menimbulkan berbagai macam permasalahan apabila kain yang dibuat memiliki fungsi lain selain hanya menjadi kain batik saja serta kurangnya variasi dalam desainnya. Motif kawung yang memiliki permasalah perlu dikembangkan dengan mengabungkan atau menambahkan dengan motif yang lain. Sehingga menghasilkan motif baru yang memiliki nilai fungsi yang lebih baik serta untuk menarik minat pembeli dengan pengembangan desain menjadi desain yang baru, meskipun tidak meninggalkan desain motif yang lama. Dari permasalahan tersebut menginspirasi desain baru dengan mengabungkan motif kawung dengan motif yang lainnya seperti motif kopi pecah dan menambahkan alur tahun kayu yang menjadi ciri khas dari batik grajen yang berasal dari limbah serbuk kayu dan banyaknya industri mebel yang menjadi ikon dari Bulakan. 


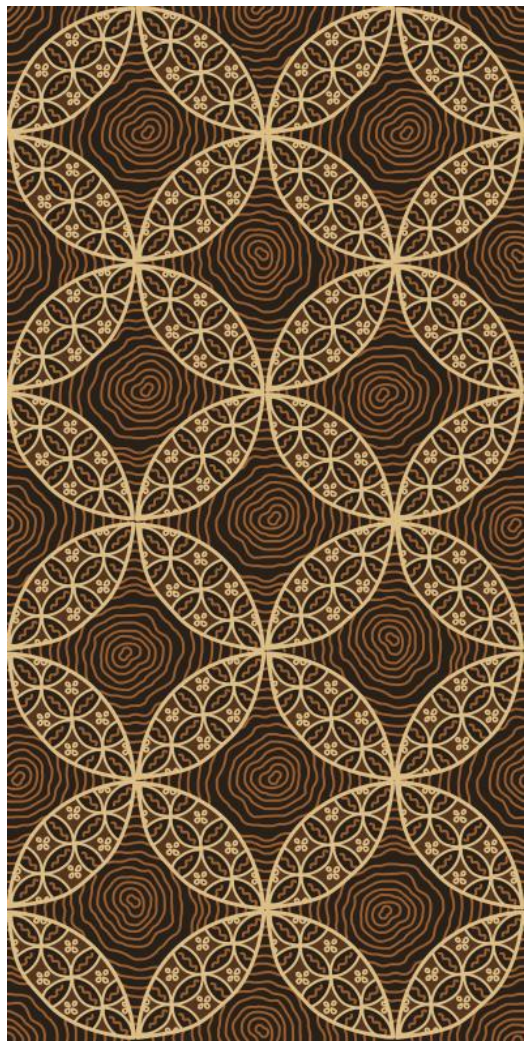

Gambar 2 Fify Fitriani,Setyawan,dan Batik Sari Rejeki, Desain Batik Grajen Kawung Kayu, 2019, sketsa

Pengembangan desain motif Kawung memiliki ukuran jarak antar kawung tidak terlalu jauh, yakni $20 \mathrm{~cm}$. proses pewarnaan yang lebih bervariasi dan tidak menggunakan bahan pewarna sintetis di dalam pembuatan batik. untuk desain ini pengrajin tidak berkomentar mengenai kekurangan desain in dan para pengrajin menerima usulan desain ini dengan baik.

\section{Tes Produk}

Proses pembuatan batik limbah grajen hampir sama seperti proses pembuatan batik pada umumnya yang membedakan adalah proses pembuatan warna yang memiliki waktu lebih panjang karena menggunakan serbuk kayu yang sudah di oven sehingga waktu yang digunakan unutk ektraksi warna lebih panjang dapat mencapai 2 hari proses pengekstrakan warna. limbah grajen dan air di rendam selama satu hari sampai air memiliki batas setengah drum, kemudian grajen dan air direbus selama satu hari sampai kadar airnya setengah drum.

Serbuk grajen yang sudah tidak bisa lagi mengeluarkan warna akan berubah menjadi kehitaman seperti kayu yang dibakar, apabila warna yang dirasa kurang kental maka akan ditambah serbuk grajen kembali dan serbuk grajen yang lama akan dikeluarkan.

Proses berikutnya adalah pemordanan kain atau warga di Bulakan menyebutnya dengan kloyor. Kain direbus selama satu jam mengunakan tawas kemudian didiamkan selama 24 jam, proses pengkloyoran ini berfungsi untuk membuka serat-serat kain dan membersihkan kain sehingga memudahkan penyerapan warna di dalam proses pewarnaan alam.

Kain melalui proses pemordanan hal berikutnya yang dilakukan adalah pencorekan (mengambar pola kain menggunakan pensil). Proses pencorekan selasai maka tahap selanjutnya adalah proses pembatikan. Proses pembatikan bisa dilakukan berulang kali di dalam pembuatan batik grajen yang dilakukan oleh home industri batik milik Bu Darsono, dikarenakan menggunakan teknik warna tutup celup, semakin banyak warna yang digunakan maka semakin banyak proses pembatikan yang dilakukan. 
Proses pembatikan tahap pertama selanjutnya adalah proses pewarnaan. Proses pewarnaan tahap pertama menggunakan limbah grajen kayu mahoni dengan fiksator kapur. Proses berikutnya adalah nemboki bagian-bagian warna apa saja yang diinginkan tetap berwarna seperti pada pewarnaan tahap pertama.

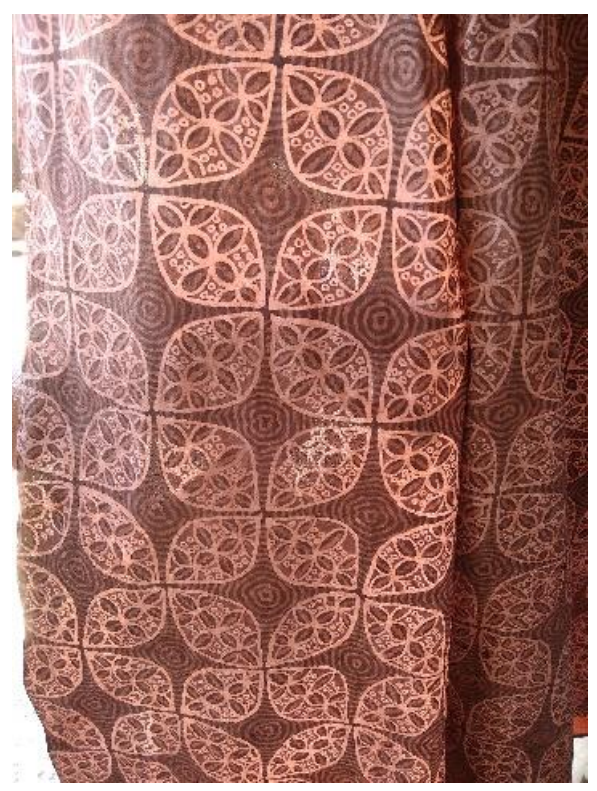

Gambar 3 Fify Fitriani, Setyawan,dan Batik Sari Rejeki, Batik Grajen Kawung Kayu, 2019,batik pada tekstil, 2400 × $1150 \mathrm{~cm}$, koleksi peneliti

Tahap berikutnya adalah proses pencelupan warna ke dalam pewarna limbah grajen mahoni dengan fiksator tunjung. Pewarnaan yang dilakukan dalam tahap ini proses pencelupan tidak sebanyak pada proses pencelupan pertama dan terakhir agar warna yang dihasilkan tidak sepekat warna terakhir. Tahap terakhir proses pembatikan dengan melakukan proses nemboki bagian-bagian yang ingin mempertahankan warna pada proses kedua.

Dilakukan proses pencelupan warna tahap terakhir dengan menggunakan pewarna limbah grajen kayu mahoni dan fiksator tunjung. Tahap terakhir di dalam proses pembuatan kain batik adalah proses penglorodan.

\section{KESIMPULAN}

Pengembangan desain batik limbah grajen mengingatkan bagaimana sebuah budaya, kebiasaan serta lingkungan tempat tinggal manusia dapat mempengaruhi bagaimana cara manusia hidup dan tinggal di wilayah tersebut sehingga menimbulkan sebuah budaya serta gaya hidup yang berbeda dari satu masyarakat dengan masyrakat yang lainnya.

Penelitian ini bertujuan untuk menggembangkan motif batik limbah grajen agar dapat menjadi ikon dari batik limbah grajen, dengan mempertimbangkan bagaimana kearifan lokal yang ada di Bulakan. Pertanyaan apakah itu batik limbah grajen terlalu dangkal dan memiskinkan pengertian mengenai batik limbah grajen. Untuk sebab itu pertanyaan yang berikutnya yang menjadi landasan penelitian adalah bagaimana latar belakang sosial budaya yang melandasi munculnya batik limbah grajen di Bulakan? Dari pertanyaanpertanyaan tersebut menghasilkan sebuah permasalahan tersendiri dalam perkembangan motif yang ada di dalam batik limbah grajen menyebabkan munculnya sebuah pertanyaan yang menghasilkan sebuah solusi untuk pengrajin batik limbah grajen bagaimana memecahkan permasalah pembuatan motif batik limbah grajen, dengan sebuah pertanyaan bagaimana mengembangkan desain motif batik limbah grajen dengan mempertimbangkan kearifan lokal yang ada di Bulakan, sehingga pemecahan motif dapat 
diproduksi dengan terus menerus, dapat diterima oleh pengrajin, menjadi ciri khas dari batik limbah grajen, serta menarik bagi masyarakat yang membeli batik limbah grajen.

Berawal dari pertanyaan-pertanyaan tersebut kemudian penelitian berjalan sehingga menghasilkan laporan penelitian seperti yang tertulis ini. Maka dengan pendekatan etnografi yang senggaja penulis pilih untuk penelitian ini dapat disimpulkan sebagai berikut:

Pertama, menjawab pertanyaan dasar apa itu batik limbah grajen dan dengan mempertimbangkan data yang berasal dikumpulkan maka dapat ditarik kesimpulan bahwa batik limbah grajen adalah batik yang bahan pewarnanya bersala dari pewarna alami dengan bahan dasar pembautan warna berupa limbah grajen (limbah serbuk kayu) dan secara visual batik limbah grajen hampir keseluruhan memiliki motif-motif yang berupa pengembangan motif-motif keraton berupa parang, kawung, tirtotejo dan kopi pecah. Yang menarik dari batik limbah grajen adalah proses pembuatan warna yang berbeda dari proses pembuatan pewarna alami biasanya, proses pembuatan pewarna dari limbah grajen memiliki waktu pembuatan yang lama dikarenakan limbah serbuk kayu berasal dari kayu yang telah menggalami pengovenan menyebabkan warna yang ada di kayu sulit untuk keluar.

Kedua, latar belakang masyarakat yang melandasi munculnya batik limbah grajen, dikarenakan banyaknya limbah grajen yang ada di lingkungan sekitar tempat tinggal pengrajin yang tidak dimanfaatkan dengan sebaik-baiknya, menyebabkan pengrajin batik memiliki ide untuk mengembangkan batik dengan pewarna alami yang berasal dari limbah grajen, serta bagaimana pengaruh budaya dan keyakinan masyarakat yang mempengaruhi perkembangan motif yang ada di Bulakan.

Ketiga, motif-motif yang muncul dan berkembang di Bulakan merupakan perkembanagn motif-motif keraton seperti parang dan kawung, sedangkan motif sendiri merupakan ruh yang menjadikan ciri khas sebuah daerah di dalam batik yang dihasilkan oleh wilayah tersebut, maka dari itu di dalam motif batik limbah grajen dibutuhkan perkembangan agar motif yang dihasilkan dapat menjadi ciri khas tersendiri yang menggambarkan kondisi wilayah tempat tinggal pengrajin batik limbah grajen.

\section{UCAPAN TERIMAKASIH}

Pada kesempatan ini saya ucapkan terimakasih kepada beberapa pihak terkait yang mendukung berjalannya proses pengerjaan Jurnal ini hingga terselesaikan. Mulai dari Perizinan, narasumber dan pihak-pihak yang mendukung sehingga memberikan kelancaran proses pengerjaan dan penyelesaian Jurnal ini. Untuk itu penulis mengucapkan banyak terimakasih kepada :

1. Morinta Rosandini., S.Ds., M.Ds. selaku editor pada jurnal ini sehingga jurnal ini dapat di selesaikan dengan baik.

2. Ibu Darsono sekeluarga selaku pemilik home industri batik grajen dengan merek dagang "Sari Rejeki" dan "Tri Rejeki", yang menunjukan bagaimana proses pembuatan batik, hingga penelitian kami dapat disempurnakan hingga selesai.

\section{DAFTAR PUSTAKA}

[1]. Haerudin A, and Farida. 2017. Limbah Serutan Kayu Matoa (Pometia pinnata) Sebagai Zat Warna Alam Pada Kain Batik Katun. Dinamika Kerajinan dan Batik: Majalah IImiah. 34(1):43-52.

[2]. Irhandayaningsih A. 2017. Pengembangan Motif Batik Temanggung Melalui Penguatan Ciri Visual Bertema Kopi. Anuva. 1(2):71.

[3]. Widodo T, and Ponimin. 2017. Desain Produk Batik Sentra Pringen Lereng Gunung Welirang Artistik dan Berkarakter. Journal of Arts, Design, Art Education and Culture Studies. 2(2):63-73. 
[4]. Spradley JP. 2007. Metode Etnografi. 2nd ed. Yogyakarta. Tiara Wacana;

[5]. Palgunadi B. 2007. Desain Produk : Desain, Desainer, dan Proyek Desain. Bandung. ITB Press; 